\title{
Assessment of squash seed vigor using computerized image analysis ${ }^{1}$
}

\author{
Patrícia Pereira da Silva ${ }^{2}$, Antonio Carlos Souza Albuquerque Barros ${ }^{3}$, \\ Júlio Marcos Filho ${ }^{4}$, Francisco Guilhien Gomes Junior ${ }^{4}$, \\ Warley Marcos Nascimento $5^{*}$
}

\begin{abstract}
The objective of this study was to determine the efficacy of the SVIS ${ }^{\circledR}$ (Seed Vigor Imaging System) to determine squash seed vigor evaluated at different stages of maturation. 'Jabras' hybrid seeds, resulting from a cross between Cucurbita maxima (female parent) and Cucurbita moschata (male parent), were used in this study. Seeds extracted from fruit at different maturation stages (harvested at 15, 30, 45, 60 and 75 days after anthesis and stored or not for 20 days after each harvest) were subjected to the following determinations: 100 seed weight, germination, saturated salt accelerated aging, and SVIS $^{\circledR}$. This computerized system provided data on indexes of seedling vigor and uniformity of seedling development and on seedling growth. Results from SVIS ${ }^{\circledR}$ were similar to information from the other vigor tests performed in this study, detecting significant differences in performance among seeds during the maturation process. This indicates that SVIS ${ }^{\circledR}$ is a reliable alternative for obtaining consistent information on the physiological potential of squash seeds.
\end{abstract}

Index terms: seed analysis, seedling growth, maturation, physiological potential, seed quality control.

\section{Avaliação do vigor de sementes de abóbora mediante a análise computadorizada de imagens de plântulas}

\begin{abstract}
RESUMO - Este trabalho procurou verificar a eficiência do SVIS ${ }^{\circledR}$ (Seed Vigor Imaging System) para determinar o vigor de sementes de abóbora colhidas durante diferentes estádios de maturação. Utilizou-se a cultivar híbrida Jabras, proveniente do cruzamento entre Cucurbita maxima (linhagem feminina) e Cucurbita moschata (linhagem masculina). As sementes foram extraídas de frutos colhidos aos 15, 30, 45, 60 e 75 dias após a antese e armazenados, ou não, durante 20 dias após cada colheita e submetidas às seguintes determinações: massa de 100 sementes, geminação, envelhecimento acelerado com solução saturada de $\mathrm{NaCl}$ e SVIS ${ }^{\circledR}$. Esta análise forneceu dados referentes aos índices de vigor e de uniformidade de desenvolvimento e ao crescimento das plântulas. Os resultados provenientes da análise computadorizada de imagens de plântulas foram semelhantes aos fornecidos pelos outros testes de vigor, detectando diferenças significativas no desempenho das sementes durante o processo de maturação. Isto demostra que o SVIS ${ }^{\circledR}$ é uma alternativa viável para a obtenção de informações consistentes sobre o potencial fisiológico de sementes de abóbora.
\end{abstract}

Termos para indexação: análise de sementes, maturação, potencial fisiológico, crescimento de plântulas, controle de qualidade de sementes.

\section{Introduction}

The physiological potential of a seed lot is generally assessed by the germination test, which is conducted under favorable controlled conditions to the species under consideration. This

\footnotetext{
${ }^{1}$ Submitted on 10/27/2016. Accepted for publication on $02 / 23 / 2017$. ${ }^{2}$ Universidade Federal de Pelotas, Ciência e Tecnologia de Sementes, 96160-970 - Capão do Leão, RS, Brasil.

${ }^{3}$ Universidade Federal de Pelotas, Faculdade de Agronomia Eliseu Maciel, Caixa Postal 354, 96010-900 - Pelotas, RS, Brasil.
}

information alone may be insufficient because, to the extent that environmental conditions deviate from those most adequate for stand establishment or for seed conservation during storage, seedling emergence may differ considerably from the standard germination determined in the laboratory (Demir, 2008).

${ }^{4}$ Departamento de Produção Vegetal, USP/ESALQ, Caixa Postal 9, 13418-900, Piracicaba, SP, Brasil.

${ }^{5}$ Embrapa Hortaliças, Caixa Postal 218, 70351-970 - Brasília, DF, Brasil.

*Corresponding author < warley.nascimento@embrapa.br> 
Immature seeds may be able to germinate, but in the first half of the period of seed development and dry matter accumulation, do not establish vigorous seedlings (Carvalho and Nakagawa, 2000). Vigor tests can provide more reliable information for monitoring the maturation process and determining seed physiological potential. They thus constitute a fundamental parameter in the composition of quality control programs.

Although vigor evaluation is important for determining the physiological potential of a seed lot, there are still necessary some adjustments, mainly in terms of standardization, precision, and speed in obtaining consistent results. Standardization is important because as production technology becomes more sophisticated, the need for superior quality seeds is increasingly evident (McDonald, 1998). This is an even more pressing need in regard to the seeds of some vegetable crops, due to the characteristics of those species and the degree of investment involved in production of most of vegetable crops.

Among the tests used for assessing the vigor of Cucurbitacea seeds, accelerated aging with the use of saturated salt solution (Abdo et al., 2005) and the cold test (Casaroli et al., $2006 \mathrm{a}, \mathrm{b}$ ) are important options. The accelerated aging test is among those most recommended for use in seed quality control programs (Marcos-Filho et al., 2000), and it stands out through its efficacy in identifying important differences in the physiological potential of seed lots and its association with seed performance over the storage period.

The accelerated aging test may have certain limitations in assessing the vigor of vegetable seeds due to the lack of uniformity of water absorption among the samples, which results in different levels of deterioration among the individuals that compose the sample. Seeking to minimize this problem, Jianhua and McDonald (1996) proposed substituting water for a saturated salt solution; that way, seed water uptake process is retarded, which also inhibits microorganism development. Several studies have confirmed the viability of this procedure, including Rodo et al. (2000) in carrot seeds, Torres and Marcos-Filho (2003) in melon, Ávila et al. (2006) in radish, Dutra and Vieira (2006) in squash, Kikuti and Marcos-Filho (2007) in cauliflower, Hyatt and TeKrony (2008) in onion and tomato, Lima and MarcosFilho (2009) in cucumber, and Lopes et al. (2013) in eggplant.

Although the accelerated aging test is recommended for evaluating seed vigor, it does not generate complete information, but only detect or emphasize important differences among seed lots, allowing better estimation of seed storability.

More recently, methods based on computerized evaluation of seedling images have been developed and used to complement information provided by the germination test (Marcos-Filho, 2015). One alternative was proposed by Sako et al. (2001), which developed a computerized system of image analysis of lettuce seedlings (the Seed Vigor Imaging System - SVIS ${ }^{\circledR}$ ) to determine the intensity, speed, and uniformity of seedling development. The technique is based on capturing digital images of seedlings of three to four days of age and processing them on a computer. This generates values regarding a vigor index (values from 0 to 1000 , directly proportional to vigor), uniformity of development index (also from 0 to 1000), and seedling length.

The procedure for the assessment of seed vigor through SVIS $^{\circledR}$ is simple, and results are obtained in a few minutes (Gomes-Junior et al., 2009); moreover, it eliminates human interference, favoring consistent results (Marcos-Filho, 2015). Several research studies have emphasized the efficiency of computerized analysis of seedlings with the SVIS ${ }^{\circledR}$ system, e.g., in assessment of seed vigor of different species such as melon (Marcos-Filho et al., 2006), lettuce (Kikuti and MarcosFilho, 2012), sweet corn (Alvarenga et al., 2012), cucumber (Chiquito et al., 2012), and eggplant (Silva and Cicero, 2014).

Thus, the objective of this study was to evaluate the efficacy of the SVIS ${ }^{\circledR}$ for determination of the physiological potential of hybrid squash seeds at different stages of development in comparison with information provided by germination and accelerated aging tests. The use of seeds with different levels of maturation was based on usual variation in vigor during seed development, information that is widely available in the literature. This variation allows assessment of the sensitivity of tests to identify differences in vigor.

\section{Materials and Methods}

The study was conducted in the Seed Analysis and Image Analysis laboratories of the Department of Crop Science/Escola Superior de Agricultura "Luiz de Queiroz"/ Universidade de São Paulo and in the Seed Laboratory of Embrapa Hortaliças/Brasília, DF, from January to February 2013. Seeds of 'Jabras' hybrid squash, which is a result of the cross Cucurbita maxima (female parent) x Cucurbita moschata (male parent) were used; seeds were produced in a protected area of the experimental field of Embrapa Hortaliças in Brasília, DF, from May to October 2012, through manual pollination. Fruits were harvested at 15, 30, 45, 60 and 75 days after anthesis (DAA) to obtain materials with differences in physiological potential. At each designated time, 30 fruits were harvested, twenty of which were stored for twenty days in plastic boxes at room temperature; seeds from the other fruits were extracted immediately after harvest. Seeds were washed in running water and superficially dried at room temperature for 24 hours. After that, they were dried until 
reaching approximately $10 \%$ water content in an air circulation chamber at $32{ }^{\circ} \mathrm{C}$ for 48 hours and then processed with the aid of a pneumatic separator in laboratory for elimination of lighter impurities and malformed seeds. This same procedure was adopted for management of seeds from the stored fruits.

After seed drying and processing, the following determinations were performed:

a) Water content: evaluated by the oven method at $105^{\circ} \mathrm{C}$, with two replications for each treatment (harvest time $\mathrm{x}$ storage), according to the Rules for Seed Testing (Brasil, 2009).

b) 100 seed weight: eight subsamples of 100 dry seeds from each treatment were weighed, and the mean of the results was expressed in $\mathrm{g} /$ treatment (Brasil, 2009).

c) Germination: conducted with four replications of 50 seeds for each treatment in rolls of "germitest" type paper towel moistened with water in the amount of two times the weight of the dry paper, under alternate temperatures $\left(20^{\circ} \mathrm{C}-30^{\circ} \mathrm{C}+8 \mathrm{~h}\right.$ of light). Seedlings were recorded at four days (germination first count) and at eight days after sowing, calculating the percentages of normal seedlings, according to the criteria established by the Rules for Seed Testing (Brasil, 2009); results were expressed as mean percentage per treatment.

d) Saturated salt accelerated aging (SSAA): 250 seeds from each treatment were uniformly distributed on an aluminum screen fastened in a plastic box $(11 \mathrm{~cm} \mathrm{x} 11 \mathrm{~cm} \times$ $3.5 \mathrm{~cm}$ ), containing $40 \mathrm{~mL}$ of saturated $\mathrm{NaCl}$ solution ( $40 \mathrm{~g}$ of $\mathrm{NaCl} / 100 \mathrm{~mL}$ of water). The boxes containing the seeds were closed and kept at $41{ }^{\circ} \mathrm{C}$ for 72 hours in an accelerated aging chamber. After that period, seeds were tested for germination as above, with interpretation at four days after sowing.

e) Computerized analysis of seedling images (Seed Vigor Imaging System - SVIS ${ }^{\circledR}$ ): to obtain seedlings for image analyses, five replications of 20 seeds were used for each treatment; seeds were placed to germinate on paper toweling moistened with water in the amount of two times the weight of the dry paper, at $25{ }^{\circ} \mathrm{C}$. Seedling images were captured on an HP Scanjet 200 scanner fixed upside down inside an aluminum box ( $60 \mathrm{~cm} \times 50 \mathrm{~cm} \times 12 \mathrm{~cm}$ ) and operated with 100 dpi resolution, as described by Marcos-Filho et al. (2009). For that purpose, the three day old seedlings were transferred from the roll of paper toweling to a sheet of black construction paper with dimensions of $30 \mathrm{~cm} \times 22 \mathrm{~cm}$ (corresponding to the useful area of the scanner surface). The scanned images were analyzed by the Seed Vigor Imaging System - SVIS ${ }^{\circledR}$ software, installed in a Pentium IV computer with a CPU of 2.0 GHz, 768 MB RAM, and HD of 40 GB, with a Windows XP Professional operating system. After analysis and evaluation of each seedling, the program generated numerical values regarding the vigor index (values from 0 to 1000 , directly proportional to vigor), uniformity of seedling development index (also from 0 to 1000), and seedling length $(\mathrm{cm})$ as reported by Marcos-Filho et al. (2006), Marcos-Filho et al. (2009), Chiquito et al. (2012), and Silva and Cicero (2014).

The trials were conducted according to a completely randomized experimental design, with lots distributed according to a $5 \times 2$ factorial arrangement (five harvest times and two periods of fruit storage). The data in percentage were subjected to analysis of variance and means were compared by the Tukey test $(p \leq 0.05)$. After analysis of variance, regression analyses were conducted by the PROC REG procedure of the SAS computational program (SAS 9.1.3, 2000-2004) for the results of the germination, first count of germination, accelerated aging, and 100 seed weight tests.

\section{Results and Discussion}

Analysis of the data regarding the effects of the treatments (harvest times and temporary storage) on the physiological potential of the seeds showed significant differences in all the parameters evaluated, indicating that the tests conducted were sensitive for detecting difference among the physiological performances of the seeds during the stages of maturation.

In general, the performance of the seeds from the fruit stored temporarily (20 days) after each harvest, and only then extracted from the fruit, was better than that of the seeds immediately extracted after each harvest. The values obtained for the 100 seed weight were similar, regardless of whether the seeds had been temporarily stored or not (Figure 1); that indicates that storage did not lead to additional differences in dry matter accumulation, confirming the observations made by Dias et al. (2006). Seed weight varies according to the stage of maturation, and may be related to seed vigor.

The literature documents that seeds produced in fleshy fruit are favored by temporary storage for 10 to 20 days after harvest in well-ventilated storage rooms with mild temperature; this benefit is more evident for seeds harvested during the initial stages of maturation (Dias, 2009), as observed in this study. This storage not only considerably reduces the risks of prolonged exposure of fruit and seeds to unfavorable field conditions, but also allows natural complementation of maturation and adjustments of components at the end of syntheses processes. As emphasized by Villiers and Edgecumbe (1975), it is probable that seeds kept within the fruit maintain high water content that is sufficient for repair of cell structure, a decisive aspect for maintaining seed viability and vigor.

In studies on seed maturation, it is recommended that seeds remain attached to the fruit for a few days after harvest (Marcos-Filho, 2015). This is because rapid drying 
of seeds after extraction accentuates destructuring of the cell membrane system and impedes efficient action of mechanisms for protection against rapid desiccation, resulting in serious losses to seed physiological potential. Sensitivity to desiccation was evident in the materials harvested at 15 and at 30 days after anthesis (DAA) and after rapid drying at 45 DAA (Figures 2 to 4 and Table 1).

Slower dehydration of seeds still attached to the fruit does not abruptly interrupt the processes of reserve and enzyme synthesis, allowing adequate organization of the cell membrane system (Adams and Rinne, 1980; Samarah et al., 2009). In this respect, as emphasized by TeKrony and Egli (1995), during maturation of seeds produced in fleshy fruit normally achieve maximum vigor some days after physiological maturity (maximum dry weight).

In respect to germination, values increased in fruit harvested as of $45 \mathrm{DAA}$, with a certain stability from 60 to 75 DAA; maximum germination (97\%) was achieved at 75

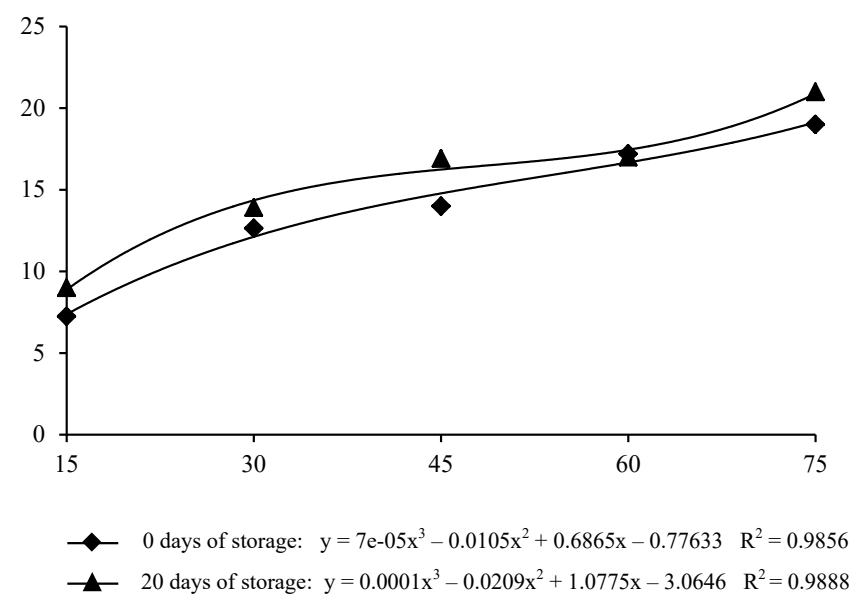

Figure 1. Mean 100 seed weight of hybrid squash seeds from fruit harvested at 15, 30, 45, 60 and 75 days after anthesis (DAA) and temporarily stored for 0 and 20 days.

Table 1. Analysis of vigor and uniformity of seedling development indexes and length of seedlings, determined by SVIS $®$ in hybrid squash seeds from fruit harvested at 15, 30, 45, 60 and 75 days after anthesis (DAA) and temporarily stored for 0 and 20 days.

\begin{tabular}{|c|c|c|c|c|c|c|c|c|c|c|}
\hline \multirow{3}{*}{ Parameter } & \multicolumn{10}{|c|}{ Harvest times } \\
\hline & \multicolumn{2}{|c|}{$15 \mathrm{DAA}$} & \multicolumn{2}{|c|}{30 DAA } & \multicolumn{2}{|c|}{$45 \mathrm{DAA}$} & \multicolumn{2}{|c|}{$60 \mathrm{DAA}$} & \multicolumn{2}{|c|}{75 DAA } \\
\hline & $0 \mathrm{~d}$ & $20 \mathrm{~d}$ & $0 \mathrm{~d}$ & $20 \mathrm{~d}$ & $0 \mathrm{~d}$ & $20 \mathrm{~d}$ & $0 \mathrm{~d}$ & $20 \mathrm{~d}$ & $0 \mathrm{~d}$ & $20 \mathrm{~d}$ \\
\hline Vigor (índex) ${ }^{(*)}$ & $0 \mathrm{~d}$ & $0 \mathrm{~d}$ & $0 \mathrm{~d}$ & $102 \mathrm{c}$ & $0 \mathrm{~d}$ & $876 \mathrm{a}$ & $789 \mathrm{ab}$ & $855 \mathrm{a}$ & $834 \mathrm{a}$ & $884 \mathrm{a}$ \\
\hline $\begin{array}{l}\text { Uniformity of } \\
\text { development (índex) }\end{array}$ & $0 \mathrm{~d}$ & $0 \mathrm{~d}$ & $0 \mathrm{~d}$ & $3.1 \mathrm{~d}$ & $0 \mathrm{~d}$ & $753 \mathrm{~b}$ & $688 \mathrm{c}$ & $832 \mathrm{~b}$ & $949 \mathrm{a}$ & $844 \mathrm{~b}$ \\
\hline Seedling length $(\mathrm{cm})$ & $0 \mathrm{~d}$ & $0 \mathrm{~d}$ & $0 \mathrm{~d}$ & $0.1 \mathrm{~d}$ & $0 \mathrm{~d}$ & $4.4 \mathrm{bc}$ & $4.0 \mathrm{c}$ & $5.2 \mathrm{~b}$ & $6.8 \mathrm{a}$ & $5.0 \mathrm{~b}$ \\
\hline
\end{tabular}

(*)Comparison of mean values within each line (Tukey test, $\mathrm{p} \leq 0.05$ ).
DAA; performance of stored seeds was superior, especially at 45 DAA (Figure 2). In a study with zucchini seeds, the germination test allowed detection of different levels of physiological potential among seed lots (Casaroli et al., 2009), but this information was not reflected by seedling emergence in the field.

The variations in the data in regard to the germination first count results were similar to those reported for total germination (Figure 3); in other words, an increase in seed vigor was observed up to $60 \mathrm{DAA}$, which then stabilized. Results from the germination first count are frequently used to complement information regarding the vigor of seed lots. According to Nakagawa (1999), it indirectly evaluates the speed of germination and has been used to obtain information regarding the physiological potential of seed lots of various species, although it is not able to identify narrow variations in vigor.

Seed performance in the accelerated aging test

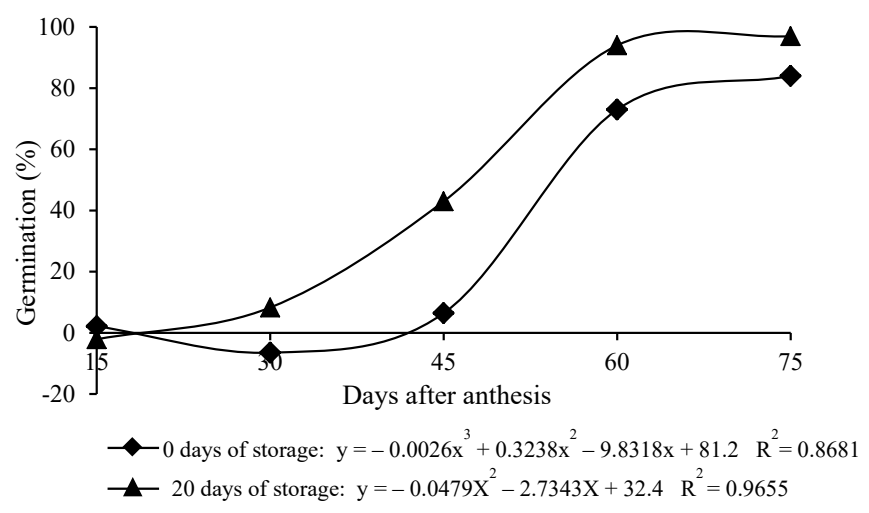

Figure 2. Mean germination of hybrid squash seeds from fruit harvested at 15, 30, 45, 60 and 75 days after anthesis (DAA) and temporarily stored for 0 and 20 days. 
showed progressive growth in fruits harvested from 45 DAA (Figure 4), confirming the observations made from evaluations of germination and the high sensitivity of this vigor test (Baalbaki et al., 2009); seeds from fruit harvested up to 30 DAA were impaired as a consequence of the conditions of this test. The efficacy of the procedure using a saturated $\mathrm{NaCl}$ solution for evaluation of vegetable seed vigor has been emphasized by several authors, including Rodo et al. (2000) in carrot seeds, Torres and Marcos-Filho (2003) in melon, Abdo et al. (2005) in cucumber, Bhéring et al. (2006) in hot pepper, Dutra and Vieira (2006) in squash, Hyatt and TeKrony (2008) in onion, and Kikuti and Marcos-Filho (2012) in lettuce. The SSAA has advantages in regard to simplicity, similarity in regard to levels of deterioration (closer water contents) observed during seed storage on a commercial scale, and lower additional effect of microorganisms, minimizing the effects of pathogens on the results of the test (Jianhua and McDonald, 1996; Marcos-Filho, 2015).

At the same time, through SVIS ${ }^{\circledR}$ analyses, significant differences were identified among the vigor index, uniformity of development index, and seedling growth as the seeds matured (Table 1).

The values obtained in SVIS $^{\circledR}$ analyses up to 45 DAA for the seeds extracted soon after harvest were near zero, similar to those observed for germination and vigor (germination first count and SSAA) tests. The values obtained for the indexes of vigor and of uniformity of seedling development from seeds harvested at 60 DAA and 75 DAA likewise stood out; actually, at that time, the highest values for seedling length were observed, just as reported above for results of other tests.

Consequently, the results of this study once more show the consistency of the information provided by SVIS ${ }^{\circledR}$ analyses in comparison to that derived from more traditional tests. These observations confirmed the success obtained by several authors that worked with Cucurbitacea seeds (MarcosFilho et al., 2006; Chiquito et al., 2012) and seeds from other vegetable species mentioned above.

Determination of seed vigor with use of the SVIS $^{\circledR}$ is simple and fast and significantly reduces the possibility of human interference. The period necessary for generating vigor indexes from scanned images of three day old seedlings is shorter than that required for conducting the accelerated aging test (Hoffmaster et al., 2005), for example. The results, in a 50-seed sample, can be obtained in two to three minutes, according to Gomes-Junior et al. (2009), and the information obtained is highly reliable.

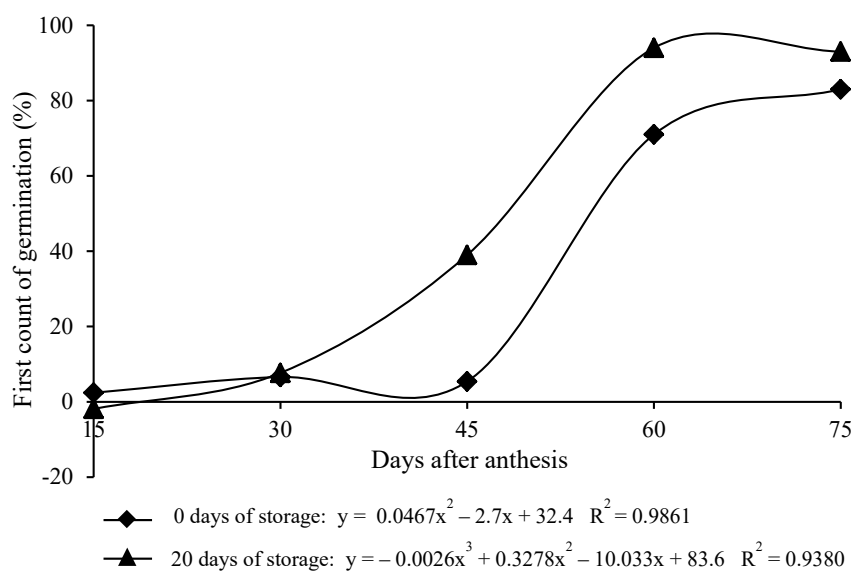

Figure 3. Germination first count of hybrid squash seeds from fruit harvested at 15, 30, 45, 60 and 75 days after anthesis (DAA) and temporarily stored for 0 and 20 days.

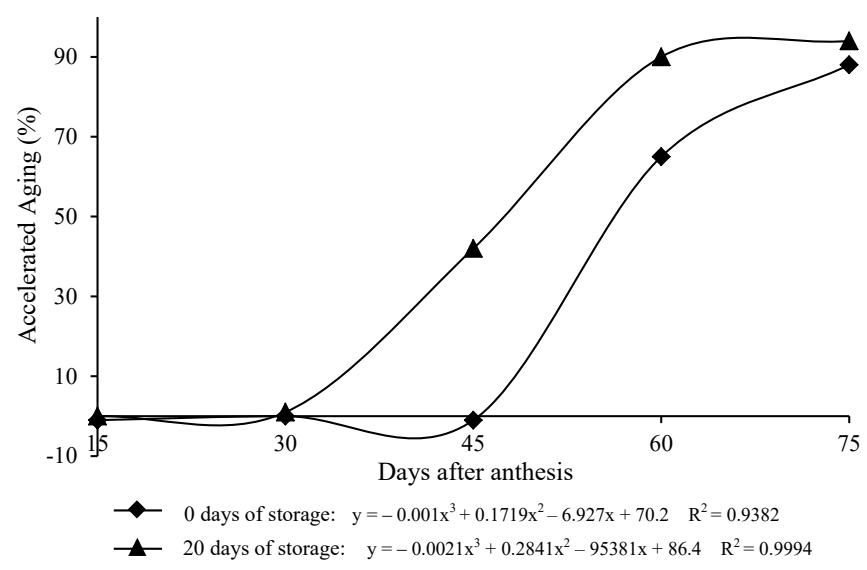

Figure 4. Saturated salt accelerated aging in hybrid squash seeds from fruit harvested at 15, 30, 45, 60 and 75 days after anthesis (DAA) and temporarily stored for 0 and 20 days.

\section{Conclusions}

Automated image analysis of seedlings performed by SVIS $^{\circledR}$ allows identification of differences in the physiological potential of squash seeds in a comparable way to information provided by the germination and saturated salt accelerated aging tests. Vigor and uniformity of seedling development indexes and seedling growth are effective parameters for composing quality control programs for seeds of this species. 


\section{References}

ABDO, M.T.V.N.; PIMENTA, R.S.; PANOBIANCO, M.; VIEIRA, R.D. Testes de vigor para avaliação de sementes de pepino. Revista Brasileira de Sementes, v.27, p.195-198, 2005. http:/www.scielo.br/ $\mathrm{pdf} / \mathrm{rbs} / \mathrm{v} 27 \mathrm{n} 1 / 25199 . \mathrm{pdf}$

ADAMS, C.A.; RINNE, R.W. Moisture content as a controlling factor in seed development and germination. International Review of Cytology, v.1, n.1, p.1-8, 1980.

ALVARENGA, R.; MARCOS-FILHO, J; GOMES JUNIOR, F.G. Avaliação do vigor de sementes de milho super doce por meio da análise computadorizada de imagens de plântulas. Revista Brasileira de Sementes, v.34, n.3, p.488-494, 2012. http://dx.doi.org/10.1590/ S0101-31222012000300017

ÁVILA, P.F.V.; VILLELA, F.A.; ÁVILA, M.S.V. Teste de envelhecimento acelerado para avaliação do potencial fisiológico de sementes de rabanete. Revista Brasileira de Sementes, v.28, n.1, p.52-58, 2006. http://dx.doi. org/10.1590/S0101-31222006000300008

BAALBAKI, R.; BAALBAKI, R.Z.; ELIAS, S.; MARCOS-FILHO, J.; McDONALD, M.B. Seed vigor testing handbook. Ithaca, New York: Association of Official Seed Analysts, 2009. 346p.

BHÉRING, M.C.; DIAS, D.C.F.S.; VIDIGAL, D.S.; NAVEIRA, D.S.P. Teste de envelhecimento acelerado em sementes de pimenta. Revista Brasileira de Sementes, v.28, n.3, p.64-71, 2006. http:// dx.doi.org/10.1590/S0101-31222006000300010

BRASIL. Ministério da Agricultura, Pecuária e Abastecimento. Regras para análise de sementes. Ministério da Agricultura, Pecuária e Abastecimento. Secretaria de Defesa Agropecuária. Brasília: MAPA/ACS, 2009, 395p. http://www.agricultura.gov.br/arq_editor/ file/2946_regras_analise_sementes.pdf

CARVALHO, N.M.; NAKAGAWA, J. Sementes: ciência, tecnologia e produção. Jaboticabal, FUNEP. 2000. 588p.

CASAROLI, D.; GARCIA, D.C.; MENEZES, N.L.; MUNIZ, M.F.B.; MANFRON, P.A. Testes para determinação do potencial fisiológico de sementes de abóbora. Acta Scientiarum Agronomy, v.31, n.2, p.337-343, 2009. http://www.scielo.br/scielo.php?script=sci_ arttext\&pid $=$ S1807-86212009000200022

CASAROLI, D.; GARCIA, D.C.; MENEZES, N. L.; MUNIZ, M. F.B.; BAHRY, C.A. Teste de envelhecimento acelerado em sementes de abóbora. Revista da Faculdade de Zootecnia, Veterinária e Agronomia, v.13, n.2, p.97-107, 2006a. http://www. scielo.br/scielo.php?script $=$ sci_nlinks\&ref $=000105 \&$ pid $=$ S 1807 $8621200900020002200011 \& \operatorname{lng}=$ en

CASAROLI, D.; GARCIA, D.C.; MEDEIROS, N. L.; MUNIZ, M.F.B.; BAHRY, C.A. Teste de frio sem solo em sementes de abóbora. Ciência Rural, v. 36, n. 6, p. 1923-1926, 2006b. http:// dx.doi.org/10.1590/S0103-84782006000600042

CHIQUITO, A.A.; GOMES JUNIOR, F.G.; MARCOS-FILHO, J. Assessment of physiological potential of cucumber seeds using the software Seedling Vigor Imaging System ${ }^{\circledR}$. Revista Brasileira de Sementes, v.34, n.2 p.255-263, 2012. http://dx.doi.org/10.1590/ S0101-31222012000200010
DEMIR, I. Prediction of germination and vigour in naturally aged commercially available seed lots of cabbage (Brassica oleracea var. capitata) using the bulk conductivity method. Seed Science and Technology, v.36, n.3, p.509-523, 2008. https://doi.org/10.15258/ sst.2008.36.3.01

DIAS, D.C.F.S. Desenvolvimento, maturação e colheita de sementes de hortaliças. IN: NASCIMENTO, W.M. (Ed.). Tecnologia de sementes de hortaliças. Brasília, Embrapa Hortaliças, p.11-74, 2009.

DIAS, D.C.F.S.; RIBEIRO, F.P.; DIAS, L.A.S.; SILVA, D.J.H.; VIDIGAL, D.S. Tomato seed quality in relation to fruit maturation and post-harvest storage. Seed Science and Technology, v.34, n.3, p.691-699, 2006. https://doi.org/10.15258/sst.2006.34.3.15

DUTRA, A.S.; VIEIRA, R.D. Accelerated ageing tests to evaluate seed vigor in pumpkin and zucchini seeds. Seed Science and Technology, v.34, n.1, p.209-214, 2006. https://doi.org/10.15258/ sst.2006.34.1.24

GOMES-JUNIOR, F.G.; MONDO, V.H.V.; CICERO, S.M.; McDONALD, M.B.; BENNETT, M.A. Evaluation of priming effects on sweet corn seeds by SVIS. Seed Technology, v.31, n.1, p.95-100, 2009. http://www.jstor.org/stable/23433510

HOFFMASTER, A.L.; XU, L.; FUJIMURA, K.; McDONALD, M.B.; BENNET, M.A.; EVANS, A.F. The Ohio State University seed vigor imaging system (SVIS) for soybean and corn seedlings. Seed Science and Technology, v.27, p.7-24, 2005. http://www.jstor. org/stable/23433211

HYATT, J.E.; TEKRONY, D.M. Factors influencing the saturated salt accelerated aging test in tomato and onion. Seed Science and Technology, v.36, n.3, p.534-545, 2008. https://doi.org/10.15258/ sst.2008.36.3.03

JIANHUA, Z:; McDONALD, M.B. The saturated salt accelerated aging test for small-seeded crops. Seed Science and Technology, v.25, p.123-131, 1996. http://cat.inist. fr/?aModele $=$ afficheN\&cpsidt $=268214$

KIKUTI, A.L.P.; MARCOS-FILHO, J. Potencial fisiológico de sementes de couve-flor e desempenho das plantas em campo. Revista Brasileira de Sementes, v.29, n.1, p.107-113, 2007. http://dx.doi. org/10.1590/S0101-31222007000100015

KIKUTI, A.L.P. ; MARCOS-FILHO, J. Testes de vigor em sementes de alface. Horticultura Brasileira, v.30, p. 44-50, 2012. http://www. scielo.br/pdf/hb/v30n1/v30n1a08.pdf.

LIMA, L.B.; MARCOS- FILHO, J. Condicionamento fisiológico de sementes de pepino e relação com desempenho das plantas em campo. Revista Brasileira de Sementes, v. 31, p.27-37, 2009. http:// www.producao.usp.br/handle/BDPI/5337

LOPES, M.M.; SILVA, C.B.; VIEIRA, R.D. Physiological potential of eggplant seeds. Journal of Seed Science, v.35, n.2, p.225-230, 2013. http://dx.doi.org/10.1590/S2317-15372013000200012

MARCOS-FILHO, J. Fisiologia de sementes de plantas cultivadas. Londrina, ABRATES, 2015. 659p. 
MARCOS-FILHO, J.; KIKUTI, A.L.P.; LIMA, L.B. Métodos para avaliação do vigor de sementes de soja, incluindo a análise computadorizada de imagens. Revista Brasileira de Sementes, v.31, n.1, p.102-112, 2009. http://dx.doi.org/10.1590/S010131222009000100012

MARCOS- FILHO, J.; NOVEMBRE, A.D.L.C.; CHAMMA, H.M.C.P. Tamanho da semente e teste de envelhecimento acelerado para soja. Scientia Agricola, v.57, n.3, p.473-482, 2000. http:// dx.doi.org/10.1590/S0103-90162000000300016

MARCOS-FILHO, J.; BENNETT, M.A.; McDONALD, M.B.; EVANS, A.F.; RASSBAUGH, E.M. Assessment of melon seed vigour by an automated computer imaging system compared to traditional procedures. Seed Science and Technology, v.34, p.485497, 2006. https://doi.org/10.15258/sst.2006.34.2.23

McDONALD, M.B. Improving our understanding of vegetable and flower seed quality. Seed Technology, v.20, p.121-124, 1998. http:// www.jstor.org/stable/23433016?seq=1\#page_scan_tab_contents

NAKAGAWA, J. Testes de vigor baseados no desempenho das plântulas. IN: KRZYZANOWSKI, F.C.; VIEIRA, R. D.; FRANCANETO, J. B. (Ed.). Vigor de sementes: conceitos e testes. Londrina, ABRATES, 1999. p. 1-20.

RODO, A.B.; PANOBIANCO, M.; MARCOS-FILHO, J. Metodologia alternativa do teste de envelhecimento acelerado para sementes de cenoura. Scientia Agricola, v.57, n.2, p.289-292, 2000. http://dx.doi. org/10.1590/S0103-90162000000200015
SAKO, Y.; McDONALD, M.B.; FUJIMURA, K.; EVANS, A.F.; BENNETT, M.A. A system for automated seed vigour assessment. Seed Science and Technology, v.29, n.3, p.625-636, 2001. http://www. scielo.br/scielo.php?script $=$ sci_nlinks\&ref $=000134 \&$ pid $=$ S0101$3122200900010001200016 \& \operatorname{lng}=$ en

SAMARAH, N.H.; MULLEN, R.E.; GOGGI, S.; GAUL, A. Effect of drying treatment and temperature on soybean seed quality during maturation. Seed Science and Technology, v.37, n.2, p.469-473, 2009. https://doi.org/10.15258/sst.2009.37.2.20

SILVA, V.N.; CICERO, S.M. Análise de imagens de plântulas para avaliação do potencial fisiológico de sementes de berinjela. Horticultura Brasileira, v.32, n.2, p.145-15, 2014. http://www. scielo.br/pdf/hb/v32n2/0102-0536-hb-32-02-00145.pdf.

TEKRONY, D.M.; EGLI, D.B. Accumulation of seed vigour during development and maturation. IN: ELLIS, R.H.; BLACK, M.; MURDOCH, A.J. (Ed.). Proceedings of the fifth international workshop on seeds. Reading, 1995.p.369-384.

TORRES, S.B.; MARCOS-FILHO, J. Accelerated aging of melon seeds. Scientia Agricola, v.60, n.1, p.77-82, 2003. http://dx.doi. org/10.1590/S0103-90162003000100012

VILLIERS, T.A.; EDGECUMBE, D.J. On the causes of seed deterioration in dry storage. Seed Science and Technology, v.3, n.3, p. 761-774, 1975. 